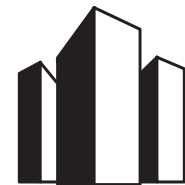

УДК 35.071:338:504

doi: 10.15421/1520171

\section{Напрями вдосконалення організаційної структури державного управління у сфері екології на регіональному рівні}

\author{
O.I. Матюшенко, 3.О. Надюк \\ lena-matushenko@ukr.net,zinoviynadyuk@ukr.net \\ Національна академія внутрішніх справ, \\ 03035, Київ, пл.Солом'янська, 1
}

У статті досліджується організаційна структура державного управління в екологічній сфері. На підставі проведеного аналізу виявлено, що в Україні відсутня єдина (типова) структура підрозділу обласної державної адміністрації, який здійснював би державне управління в екологічній сфері. Також констатовано, що створення і реорганізація відділів, секторів на рівні департаментів/управлінь $є$ хаотичними, безсистемними i, вочевидь, продиктовані різними причинами (фінансовими, індивідуально-психологічними, корупційними та ін.), а не змістовним наповненням (логікою діяльності) і структурною підзвітністю вищого управлінського рівня. Запропоновано авторську організаційну структуру Департаменту екології і природних ресурсів обласної державної адміністрації. У його структурі окремо виділено Управління забезпечення діяльності Департаменту. Здійснено порівняння організаційної структури Міністерства екології і природних ресурсів України з пропонованим нами Департаментом екології і природних ресурсів обласної державної адміністрації на предмет відповідності управлінської вертикалі. Розроблено типовий штатний розпис і внутрішньоструктурне підпорядкування Департаменту екології і природних ресурсів обласної державної адміністрації.

Ключові слова: департамент; державне управління; Міністерство екології і природних ресурсів; обласна державна адміністрація; організаційна структура; Україна; штатний розпис

\title{
Directions of improvement for public administration institutional structure in field of ecology at regional level
}

\author{
O.I. Matyushenko, Z.O. Nadyuk \\ lena-matushenko@ukr.net,zinoviynadyuk@ukr.net \\ National academy of internal affairs. \\ 1, Solomjanska Sq., 03035, Kyiv, Ukraine
}

Based on the analysis of the organizational structure of public authorities at national and regional level in volved in the process of governance in the environmental field as well as their legal security it was found that at the regional level, in regions there are different units (departments, management authorities, divisions, sectors) that coordinate the process of public administration in the environmental field. In order to offer its own structure unit of state administration, to deal with environmental issues it is analyzed the organizational structures of central executive authority in the field of ecology - the Ministry of Ecology and Natural Resources of Ukraine at the national level and the organizational structures of departments / offices of Ecology and Natural Resources regional administrations respectively, at the regional level. As it is determined there is no typical structure of the regional state administration unit in Ukraine. Recognized that departments and sectors uniting at the high level is chaotic, unsystematic and apparently dictated by different reasons (financial, personal and psychological, corruption etc.), not the content of (the logic of) and structural accountability to senior management level. It is offered the author organizational structure for the Ecology and Natural Resources Department of Regional State Administration. It is

Цитування даної статті: Матюшенко О.І. Напрями вдосконалення організаційної структури державного управління у сфері екології на регіональному рівні/ O.I. Матюшенко, 3.О. Надюк // Аспекти публічного управління. - 2017. - Т. 5. - № 1-2(39-40). - С. 5-12.

Citation of this article: Matyushenko O.I., Nadyuk Z.O, 2017. Napryamy vdoskonalennya orhanizatsiynoyi struktury derzhavnoho upravlinnya u sferi ekolohiyi na rehional'nomu rivni [Directions of improvement for public administration institutional structure in field of ecology at regional level]. Public administration aspects 5, 1-2(39-40), 5-12. doi: 10.15421/1520171 (in Ukrainian).

Peer-reviewed, approved and placed: 10.01 .2017 
suggested that this Department consists of three units: Department of Ecology (Department of environmental monitoring and audit department of environmental security department of planning and coordination of international projects in the environmental field); Department of Natural Resources (Department of Conservation of Natural Resources, Department of Protected Areas and Ecological Network Development, Department of Environmental Economics); Management support of the Department (Legal, Financial and Economic Division, Department of Administration Department, a department of scientific and methodological support and implementation of environmental policy in the region, sector logistics activities of the Department. Therefore such offered structure will improve the management relations between the national and regional levels of management. It is compared the organizational structure of the Ministry of Ecology and Natural Resources and the Department of Ecology and Natural Resources of Regional State Administration in order to compare management vertical. It has been developed the typical staff list for the Department of Ecology and Natural Resources of Regional State Administration.

Keywords: department; governance; Ministry of Ecology and Natural Resources; Regional State Administration; the organizational structure; Ukraine; staff list

\title{
Пути совершенствования организационной структуры государственного управления в сфере экологии на региональном уровне
}

\author{
Е.И. Матюшенко, 3.А. Надюк \\ lena-matushenko@ukr.net,zinoviynadyuk@ukr.net \\ Национальная академия внутренних дел, \\ 03035, Киев, пл. Соломенская, 1
}

В статье исследуется организационная структура государственного управления в сфере экологии на региональном уровне. На основании проведенного анализа выявлено, что в Украине отсутствует единая (типовая) структура подразделения областной государственной администрации, которое осуществляло бы государственное управление в экологической сфере. Также констатировано, что создание и реорганизация отделов, секторов на уровне департаментов / управлений являются хаотичными, бессистемными и, очевидно, продиктованными различными причинами (финансовыми, индивидуально-психологическими, коррупционными и др.), а не содержательным наполнением (логикой деятельности) и структурной подотчетностью высшего управленческого уровня. Предложена авторская организационная структура Департамента экологии и природных ресурсов областной государственной администрации. В его структуре отдельно выделено Управление обеспечения деятельности Департамента. Проведено сравнение организационной структуры Министерства экологии и природных ресурсов Украины с предлагаемым нами Департаментом экологии и природных ресурсов областной государственной администрации на предмет соответствия управленческой вертикали. Разработано типовое штатное расписание и внутриструктурное подчинение Департамента экологии и природных ресурсов областной государственной администрации.

Ключевые слова: департамент; государственное управление; Министерство экологии и природных ресурсов, областная государственная администрация; организационная структура; Украина; штатное расписание

Постановка проблеми. Державне управління в екологічній сфері у сучасній світовій практиці традиційно здійснювалося в межах існуючих державних структур, часом зі створенням спеціалізованих підрозділів для виконання природоохоронних функцій [5]. Організаційна структура цих підрозділів різна. $Є$ потреба розробки єдиної (типової) організаційної структури на регіональному рівні, що дасть змогу налагодити ефективнішу управлінську взаємодію між рівнями управління.

Аналіз досліджень і публікацій. Упродовж останніх років вийшла значна кількість публікацій щодо досліджень державного управління в екологічній сфері. Зокрема, загальні питання процесу екологізації суспільних процесів висвітлено у працях В. Шевчука, Ю.Саталкіна, В.Навроцького. Порівняння способів та методів екологічного управління в різних країнах світу здійснено в праці В. Лозанського. Екологічні аспекти регіонального розвитку досліджено в праці Б. Буркинського та Н. Ковальової. Різним особливостям механізму державного управління в екологічній сфері присвячені праці В. Бакуменка, О.О. Веклич, Я. С. Витвицького, М. С. Волошин, Б. Данилишина, Л. Качаровської, А.Є. Керничної, В. Кравціва, О.В. Олефірен- 
ко, М. Хилька, С. Хлобистова та ін. [1-4; 6; 8-10]. Незважаючи на значний науковий доробок вітчизняних науковців у цій площині, питання формування і модернізації управлінської структури для реалізації організаційного механізму державного управління у сфері екології як на національному, так і на регіональному рівнях висвітлені недостатньо. Викладене вище й зумовило вибір теми дослідження, визначило його мету й завдання.

Мета дослідження полягає в удосконаленні організаційного механізму державного управління у сфері екології на регіональному рівні шляхом відповідної модернізації структури облдержадміністрації. Мета зумовила виконання таких завдань:

- здійснити порівняння організаційної структури Міністерства екології і природних ресурсів України 3 пропонованим нами Департаментом екології і природних ресурсів обласної державної адміністрації на предмет відповідності управлінської вертикалі;

- розробити авторську організаційну структуру Департаменту екології і природних ресурсів обласної державної адміністрації;

- розрахувати типовий штатний розпис i внутрішньоструктурне підпорядкування новоствореного Департаменту облдержадміністраціï.

Виклад основного матеріалу. Здійснивши аналіз організаційної структури органів публічної влади на національному і регіональному рівнях, які залучені у процес державного управління в екологічній сфері i їx нормативно-правового забезпечення, ми виявили, що на регіональному рівні в областях існують різні структурні підрозділи (департаменти, управління, відділи, сектори), які координують процес державного управління в екологічній сфері.

Для того, щоб запропонувати власну структуру підрозділу облдерж- адміністрації, який займався б вирішенням екологічних питань, був здійснений аналіз організаційних структур центрального органу виконавчої влади у сфері екології - Міністерства еколо-

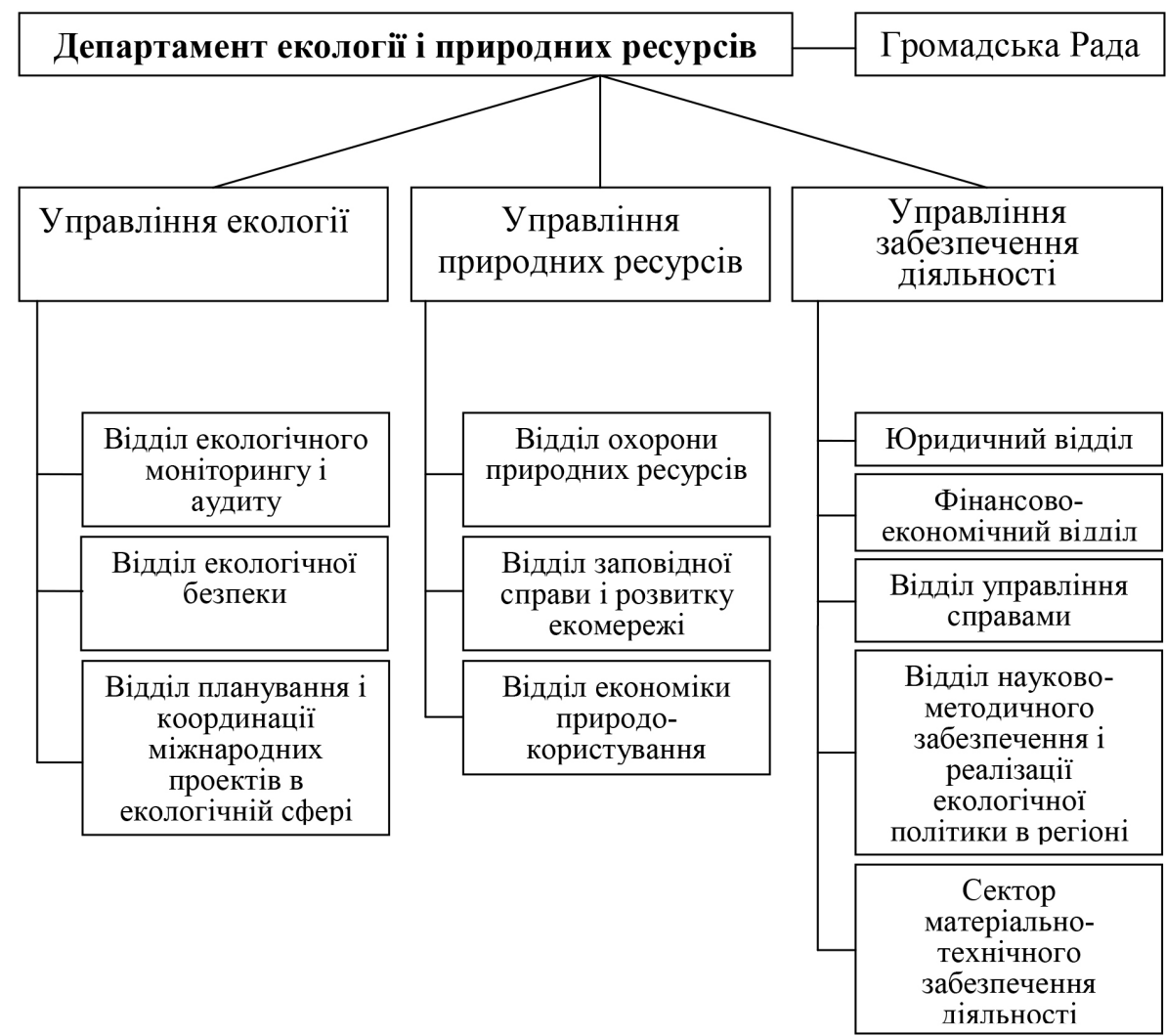

Рис. 1. Авторська організаційна структура Департаменту екології і природних ресурсів обласної державної адміністрації 
гії і природних ресурсів України на національному рівні і організаційних структур департаментів/управлінь екології і природних ресурсів обласних державних адміністрацій, відповідно, на регіональному рівні. Було виявлено, що в Україні відсутня єдина (типова) структура такого структурного підрозділу обласної державної адміністрації. Створення і реорганізація відділів, секторів на рівні департаментів/управлінь $є$ хаотичними, безсистемними i, вочевидь, продиктовані різними причинами (фінансовими, індивідуально-психологічними, корупційними та ін.), а не змістовним наповненням (логікою діяльності) i структурною підзвітністю вищого управлінського рівня. У цьому зв'язку, нами була розроблена організаційна структура Департаменту екології і природних ресурсів обласної державної адміністрації (рис.1).

На нашу думку, цей Департамент повинен містити у своєму складі три управління, а саме: управління екології; управління природних ресурсів і управління забезпечення діяльності Департаменту.

У свою чергу Управління екології Департаменту складається $з$ таких відділів:

а) відділ екологічного моніторингу і аудиту: сектор моніторингу довкілля, аудиту, експертизи та технічного регулювання; сектор атмосферного повітря;

б) відділ екологічної безпеки: сектор поводження $з$ відходами та небезпечними речовинами; сектор контролю за обігом пестицидів та агрохімікатів; сектор біобезпеки;

в) відділ планування і координації міжнародних проектів в екологічній сфері: сектор планування багато- та двосторонніх угод, договорів, заходів; сектор координації проектів в екологічній сфері.

У свою чергу Управління природних ресурсів Департаменту складається з таких відділів:

а) відділ охорони природних ресурсів: сектор охорони рослинного і тваринного світу; сектор водних екосистем, водних і земельних ресурсів;

б) відділ заповідної справи і розвитку екомережі: сектор організації, розвитку і використання природно-заповідного фонду; сектор державної охорони і управління територіями і об’єктами природно-заповідного фонду;

в) відділ економіки природокористування: сектор координації екологічних інвестицій; сектор впровадження екологічних проектів.

В організаційній структурі Департаменту екології і природних ресурсів окремо нами виділено Управління забезпечення діяльності Департаменту до складу якого пропонується включити такі підструктури:

- юридичний відділ: сектор правового забезпечення і представництва інтересів департаменту у судових і правоохоронних органах; сектор дозвільно-ліцензійної діяльності; сектор підготовки і експертизи нормативно-правових актів;

- фінансово-економічний відділ: сектор бухгалтерського обліку і звітності; сектор планування і фінансування природоохоронних заходів і розвитку об'єктів природно-заповідного фонду на території регіону;

- відділ управління справами: сектор кадрової роботи; сектор інформаційно-організаційного забезпечення; сектор мобілізаційної, режимно-секретної роботи і захисту інформаціï;

- відділ науково-методичного забезпечення і реалізації екологічної політики в регіоні: сектор наукової розробки і експертизи екологічних програм; сектор науково-методичного забезпечення діяльності департаменту;

- сектор матеріально-технічного забезпечення діяльності Департаменту.

У табл. 1 здійснено порівняння організаційної структури Міністерства екології і природних ресурсів 3 пропонованим нами Департаментом екології і природних ресурсів обласної державної адміністрації на предмет відповідності управлінської вертикалі.

Як видно 3 табл. 1 для деяких організаційних підрозділів, виокремлених на національному рівні (у міністерстві), немає прямої відповідності у структурах на регіональному рівні. Зокрема, це стосується таких підрозділів, як сектор внутрішнього аудиту; сектор контролю за виконанням доручень вищих органів державної влади; сектор державних закупівель як виокремлених підрозділів, а також відділ державного кадастру територій та об'єктів природно-заповідного фонду Департаменту заповідної території; відділ реєстру та кліматичної звітності і сектор впровадження системи торгівлі квотами на викиди парникових газів Департаменту кліматичної політики; відділ 3 питань європейської інтеграції, адаптації Європейського законодавства та супроводження міжнародних договорів і від- 
діл взаємодії з Верховною Радою та іншими органами державної влади Юридичного департаменту; відділ планування та виконання державного бюджету Департаменту економіки і фінансів; відділ управління державним майном та охорони праці Управління матеріально-технічного забезпечення.

Переважна більшість завдань, виконання яких покладено на вищеперераховані структурні підрозділи, потребують реалізації на на- ціональному, а не регіональному рівні. Тому у пропонованій нами схемі організаційної структури Департаменту екології і природних ресурсів обласної державної адміністрації, вони не відображені.

Натомість деякі повноваження, які згруповані в одному структурному підрозділі на національному рівні, на регіональному рівні передані у різні структурні одиниці. Наприклад, повноваження Департаменту екологіч-

Таблиця 1. Порівняльна таблиця відповідності організаційних структур на національному і регіональному рівнях у сфері екології і природних ресурсів

\begin{tabular}{|c|c|c|}
\hline Національний рівень & Зв'язок & Регіональний рівень \\
\hline $\begin{array}{l}\text { Управління } \\
\text { моніторингу, екологічного } \\
\text { aтмосферного повітря }\end{array}$ & & $\begin{array}{l}\text { Відділ екологічного моніторингу } i \\
\text { аудиту }\end{array}$ \\
\hline $\begin{array}{l}\text { Департамент екологічної безпеки та } \\
\text { поводження з відходами }\end{array}$ & & Відділ екологічної безпеки \\
\hline Управління міжнародної діяльності & & $\begin{array}{l}\text { Відділ планування } i \text { координацї } \\
\text { міжнародних проектів в екологічній } \\
\text { сфері }\end{array}$ \\
\hline $\begin{array}{l}\text { Департамент охорони природних } \\
\text { ресурсів }\end{array}$ & & Відділ охорони природних ресурсів \\
\hline Департамент заповідної справи & & $\begin{array}{l}\text { Відділ заповідної справи і розвитку } \\
\text { екомережі }\end{array}$ \\
\hline Департамент кліматичної політики & & $\begin{array}{ll}\text { Відділ } & \text { економіки } \\
\text { природокористування } & \end{array}$ \\
\hline Юридичний департамент & & Юридичний відділ \\
\hline Департамент економіки і фінансів & & Фінансово-економічний відділ \\
\hline Відділ роботи з персоналом & & Відділ управління справами \\
\hline $\begin{array}{lll}\text { Відділ екологічної } & \text { політики } & \text { та } \\
\text { наукової діяльності } & & \end{array}$ & & 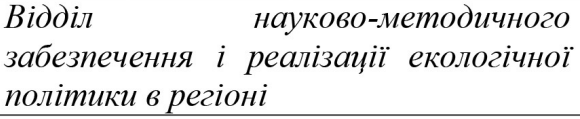 \\
\hline $\begin{array}{l}\text { Управління матеріально-технічного } \\
\text { забезпечення }\end{array}$ & & $\begin{array}{lr}\text { Сектор матеріально-технічного } \\
\text { забезпечення } \\
\text { Департаменту }\end{array}$ \\
\hline $\begin{array}{l}\text { Відділ бухгалтерського обліку } \\
\text { звітності }\end{array}$ & & \\
\hline Сектор внутрішнього аудиту & & \\
\hline $\begin{array}{l}\text { Сектор контролю за виконанням } \\
\text { доручень вищих органів державної } \\
\text { влади }\end{array}$ & & \\
\hline Сектор державних закупівель & & $\rightarrow X$ \\
\hline $\begin{array}{ll}\text { Сектор обліку дозвільної } \\
\text { документації }\end{array}$ & & \\
\hline Сектор режимно-секретної роботи & & \\
\hline $\begin{array}{l}\text { Головний спеціаліст } \\
\text { мобілізаційної роботи }\end{array}$ & & \\
\hline
\end{tabular}

Примітка: X - нема прямої відповідності 
ної безпеки та поводження з відходами Міністерства екології і природних ресурсів України (який, нагадаємо, у своєму складі містить Відділ поводження 3 відходами та небезпечними речовинами; Відділ контролю за обігом пестицидів та агрохімікатів; Відділ дозвіль- но-ліцензійної діяльності і Відділ екологічної оцінки (експертизи)) на регіональному рівні пропонується передати Відділу екологічного моніторингу і аудиту (сектор моніторингу довкілля, аудиту, експертизи та технічного регулювання) щодо екологічної оцінки (екс-

Таблиця 2. Пропонований типовий штатний розпис Департаменту екології і природних ресурсів обласної державної адміністрації

\begin{tabular}{|c|c|c|}
\hline $\begin{array}{l}\text { № } \\
\text { 3/ח }\end{array}$ & Найменування структурного підрозділу & $\begin{array}{l}\text { Чисельність } \\
\text { штатних одиниць }\end{array}$ \\
\hline & Директор Департаменту & 1 \\
\hline 1 & Управління екології: & 15 \\
\hline 2 & Відділ екологічного моніторингу і аудиту & 5 \\
\hline 3 & сектор моніторингу довкілля, аудиту, експертизи та технічного регулювання & 3 \\
\hline 4 & сектор атмосферного повітря & 2 \\
\hline 5 & Відділ екологічної безпеки: & 6 \\
\hline 6 & сектор поводження з відходами та небезпечними речовинами & 2 \\
\hline 7 & сектор контролю за обігом пестицидів та агрохімікатів & 2 \\
\hline 8 & сектор біобезпеки & 2 \\
\hline 9 & Відділ планування і координації міжнародних проектів в екологічній сфері: & 4 \\
\hline 10 & сектор планування багато- та двосторонніх угод, договорів, заходів & 2 \\
\hline 11 & сектор координації проектів в екологічній сфері & 2 \\
\hline 12 & Управління природних ресурсів & 12 \\
\hline 13 & Відділ охорони природних ресурсів: & 5 \\
\hline 14 & сектор охорони рослинного і тваринного світу & 2 \\
\hline 15 & сектор водних екосистем, водних і земельних ресурсів & 2 \\
\hline 16 & Відділ заповідної справи і розвитку екомережі: & 4 \\
\hline 17 & сектор організації, розвитку і використання природно-заповідного фонду & 2 \\
\hline 18 & $\begin{array}{l}\text { сектор державної охорони і управління територіями і об’єктами природно- } \\
\text { заповідного фонду }\end{array}$ & 2 \\
\hline 19 & Відділ економіки природокористування: & 4 \\
\hline 20 & сектор координації екологічних інвестицій & 2 \\
\hline 21 & сектор впровадження екологічних проектів & 2 \\
\hline 22 & Управління забезпечення діяльності Департаменту & 22 \\
\hline 23 & Юридичний відділ: & 6 \\
\hline 24 & $\begin{array}{l}\text { сектор правового забезпечення і представництва інтересів департаменту у } \\
\text { судових і правоохоронних органах }\end{array}$ & 2 \\
\hline 25 & сектор дозвільно-ліцензійної діяльності & 2 \\
\hline 26 & сектор підготовки і експертизи нормативно-правових актів & 2 \\
\hline 27 & Фінансово-економічний відділ: & 4 \\
\hline 28 & сектор бухгалтерського обліку і звітності & 2 \\
\hline 29 & $\begin{array}{l}\text { сектор планування і фінансування природоохоронних заходів і розвитку } \\
\text { об’єктів природно-заповідного фонду на території регіону }\end{array}$ & 2 \\
\hline 30 & Відділ управління справами: & 6 \\
\hline 31 & сектор кадрової роботи & 2 \\
\hline 32 & сектор інформаційно-організаційного забезпечення & 2 \\
\hline 33 & сектор мобілізаційної, режимно-секретної роботи і захисту інформації & 2 \\
\hline 34 & $\begin{array}{l}\text { Відділ науково-методичного забезпечення і реалізації екологічної політики в } \\
\text { регіоні: }\end{array}$ & 4 \\
\hline 35 & сектор наукової розробки і експертизи екологічних програм & 2 \\
\hline 36 & сектор науково-методичного забезпечення діяльності департаменту & 2 \\
\hline 37 & сектор матеріально-технічного забезпечення діяльності департаменту & 2 \\
\hline & 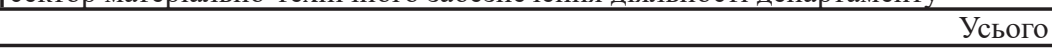 & 50 \\
\hline
\end{tabular}


пертизи); відділу екологічної безпеки (сектора поводження з відходами та небезпечними речовинами) щодо контролю за поводженням 3 відходами і небезпечними речовинами; відділу екологічної безпеки (сектору контролю за обігом пестицидів та агрохімікатів) відповідні повноваження щодо цих речовин; Юридичному відділу (сектора дозвільно-ліцензійної діяльності) щодо цієї діяльності.

Згідно 3 постановою Кабінету Міністрів України №228 від 28.02.2002р. «Про затвердження Порядку складання, розгляду, затвердження та основних вимог до виконання кошторисів бюджетних установ» [7], штатний розпис та кошторис Департаменту затверджує голова обласної державної адміністрації за пропозицією директора Департаменту. Пропонується такий штатний розпис Департаменту екології і природних ресурсів (Табл. 2).

На посадах заступників директора департаменту пропонується задіяти начальників відповідних управлінь департаменту: управління екології, управління природних ресурсів і управління забезпечення діяльності. Заступник/начальник управління забезпечення діяльності Департаменту буде також відповідати за зв'язки з громадськістю.
Висновки. Здійснивши аналіз організаційної структури органів публічної влади на національному і регіональному рівнях, які залучені у процес державного управління екологічною сферою, нами запропоновано модернізувати структуру департаментів екології і природних ресурсів облдержадміністрацій.

Пропонована нами типова структура Департаменту, на нашу думку, повинна складатися 3 таких структурних підрозділів: управління екології; управління природних ресурсів; управління забезпечення діяльності Департаменту.

Окремо виділене Управління забезпечення діяльності Департаменту складатиметься 3 таких підструктур: юридичний відділ; фінансово-економічний відділ; відділ управління справами; відділ науково-методичного забезпечення і реалізації екологічної політики в регіоні; сектор матеріально-технічного забезпечення діяльності Департаменту. Така структура пропонованого нами Департаменту сприятиме покращенню державного управління у сфері екології шляхом оптимізації управлінських зв язків (пряма відповідність і підпорядкованість) між національним і регіональними рівнями управління.

\section{БІБЛІОГРАФІЧНІ ПОСИЛАННЯ:}

1. Буркинський Б.В. Інституційний механізм реалізації екологоорієнтованих стратегічних планів розвитку національної економіки / Б.В. Буркинський, Н.І. Хумарова // Екологічні науки. - 2013. - №2. - С. 139-148.

2. Витвицький Я.С. Механізм державного управління в екологічній сфері на регіональному рівні та напрями його вдосконалення / Я.С. Витвицький, А.Є. Кернична // Актуальні проблеми державного управління. -2012. - №2 (42). - С. 178-186.

3. Екологічна складова політики сталого розвитку : [монографія] / Б.М. Данилишин; Рада по вивч. продукт. сил України. - Донецьк: Юго-Восток, Лтд, 2008. - 256 с.

4. Екологічне управління в розвинутих країнах світу в порівнянні з Україною / В. Р. Лозанський. - Х., 2000. - 68 с. - Бібліогр.: 14 назв. - укр.

5. Матюшенко О. І. Досвід управління охороною навколишнього природного середовища в економічно розвинутих країнах / О. І. Матюшенко // Держава та регіони. Сер.: Державне управління. - 2013. - № 4. - С. 37-42. - Режим доступу: http://nbuv.gov.ua/UJRN/drdu_2013_4_10.

6. Олефіренко О.В. Основні напрямки забезпечення ефективності державного екологічного управління в Україні / О.В. Олефіренко // Ефективність державного управління. - 2014. - Вип. 40. - С. 41-47. - Режим доступу: http://nbuv.gov.ua/UJRN/efdu_2014_40_7.

7. Про затвердження Порядку складання, розгляду, затвердження та основних вимог до виконання кошторисів бюджетних установ: Постанова Кабінету Міністрів України №228 від 28.02.2002 р. // Офіц.вісн.України від 15.03.2002 p. - 2002. - №9. - Стор. 101. - Ст. 414. - Код акту 21731/2002.

8. Формування та реалізація національної екологічної політики України / [Веклич О.О., Волошин С.М., Жарова Л.В. та ін.]; за наук.ред. С.О. Лизуна / ДУ ІЕПСР НАН України. - Суми: Університетська книга, 2012. - 336 с. 9. Хилько М. І. Пріоритет сталого екобезпечного розвитку / М. І. Хилько // Гілея: науковий вісник. - 2016. Вип. 111. - С. 333-339. - Режим доступу: http://nbuv.gov.ua/UJRN/gileya 201611186.

10. Хлобистов С.В. Імплементація положень конвенцій Ріо до національної політики сталого розвитку: еколого-економічні прогалини регуляторної діяльності / Є.В. Хлобистов // Ефективна економіка. - 2014. - №9. - Режим доступу: http://www.economy.nayka.com.ua/?op=1\&z=3314. 


\section{REFERENCES:}

1. Burkins'kij, B.V., 2013. Institucijnij mehanizm realizaciï ekologoorientovanih strategichnih planiv rozvitku nacional'noï ekonomiki [Institutional mechanism of ecological-oriented strategic plans for national economy development]. Environmental Sciences, 2, 139-148 (in Ukrainian).

2. Vitvic'kij, Ja.S., Kernichna, A.Ye., 2012. Mehanizm derzhavnogo upravlinnja v ekologichnij sferi na regional'nomu rivni ta naprjami jogo vdoskonalennja [mechanism of governance in the environmental field at regional level and areas to improve]. Actual problems of public administration, 2 (42).-178-186 (in Ukrainian).

3. Danilishin, B.M., 2008. Ekologichna skladova politiki stalogo rozvitku [The environmental component of sustainable development]. Donec'k: Jugo-Vostok, Ltd, 256 (in Ukrainian).

4. Lozans'kij, V.R., 2000. Ekologichne upravlinnja v rozvinutih kraïnah svitu v porivnjanni z Ukraïnoju [Environmental management in developed countries compared to Ukraine]. H. [BV], 0. - 68 p. - ISBN 5-7763-2107-7 (in Ukrainian)

5. Matjushenko, O.I., 2013. Dosvid upravlinnja ohoronoju navkolishn'ogo prirodnogo seredovishha v ekonomichno rozvinutih krajinah [Experience of management of the natural environment in economically developed countries] State and regions, 3, 37-42 (in Ukrainian).

6. Olefirenko, O.V., 2014. Osnovni naprjamki zabezpechennja efektivnosti derzhavnogo ekologichnogo upravlinnja v Ukrajini [Main directions of ensuring the effectiveness of environmental governance in Ukraine]. The efficiency of public administration, 40, 41-47 (in Ukrainian).

7. Pro zatverdzhennja Porjadku skladannja, rozgljadu, zatverdzhennja ta osnovnih vimog do vikonannja koshtorisiv bjudzhetnih ustanov: Postanova Kabinetu Ministriv Ukrajini №228 vid 28.02.2002. Ofic.visn.Ukrajini, 9. 101. (in Ukrainian).

8. Veklich, O.O., Voloshin, S.M., Zharova, L.V., 2012. Formuvannja ta realizacija nacional'noji ekologichnoji politiki Ukrajiny [Formulation and implementation of the National Environmental Policy of Ukraine]. DU IEPSR NAN Ukraine. - Sumi: Universitets'ka kniga, 336 (in Ukrainian).

9. Hil'ko, M.I., 2016. Prioritet stalogo ekobezpechnogo rozvitku [priority ecosafety sustainable development]. Gilea: Research Bulletin, 111, 333-339 (in Ukrainian).

10. Khlobystov, Iev.V., 2014. Implementacija polozhen' konvencij Rio do nacional'noji politiki stalogo rozvitku: ekologo-ekonomichni progalini reguljatornoji dijal'nosti [Implementation of the Rio conventions into national sustainable development policy: environmental and economic gaps of regulatory policy]. Efektyvna ekonomika, 9. Access: http://www.economy.nayka.com.ua/?op=1\&z=3314 (in Ukrainian). 